\title{
PRAKIRAAN CURAH HUJAN BANDARA SYAMSUDIN NOOR DENGAN ALGORITMA NEURAL NETWORK BACKPROPAGATION
}

\author{
Ir. H. M.Muflih, M.Kom \\ Email : muflihbjm@gmail.com \\ Nur Alamsyah \\ Email:alam@fti.uniska-bjm.ac.id \\ Wagino \\ Email: wagino@fti.uniska-bjm.ac.id
}

\begin{abstract}
ABSTRAK
Data curah hujan bulanan merupakan data yang djadikan tujuan untuk memprakirakan curah hujan di Bandara Syamsudin Noor Banjarbaru dengan menggunakan neural network multilayer dan algoritma backpropagation. Untuk Simulasi algoritma menggunakan software Matlab R2013a.

Parameter yang digunakan dalam penelitian menggunakan metode pembelajaran backpropagation dengan momentum, laju pemahaman (learning rate) dan MSE (Mean Square Error) melihat selisih error yang dilakukan oleh jaringan saat pelatihan maupum pengujian data, dengan arsitektur jaringan berupa 12 input, 5 Neuron lapisan layar tersembunyi (hidden layer) dan 1 output.

Dari output yang dihasilkan sudah mendekati nilai target dan telah berhasil melakukan proses dengan baik dalam mengenali target dengan pola data yang ditentukan.
\end{abstract}

Kata Kunci: Curah Hujan, Jaringan Syaraf Tiruan, backpropagation

PENDAHULUAN
Prediksi cuaca dan iklim digunakan untuk melihat kondisi alam untuk waktu mendatang dan merupakan suatu usaha manusia untuk melihat perkembangan kondisi udara yang lalu, sekarang, dan yang akan datang khususnya dalam kaitan mengantisipasinya dengan cara mengoptimalkan usaha pemantauan, pengumpulan, analisis data, hingga menjadi bentuk evaluasi atau prediksi cuaca dan iklim.

Dalam dunia penerbangan, keselamatan adalah prioritas yang paling utama. Keselamatan dalam penerbangan berkaitan dengan berbagai faktor antara lain kondisi mesin pesawat, kondisi lintasan landing dan salah satu faktor yang penting adalah cuaca. Unsur-unsur yang mempengaruhi cuaca dan iklim adalah suhu, kelembaban, tekanan udara, kecepatan angin dan curah hujan. Rekomendasi kelayakan penerbangan dipengaruhi oleh curah hujan dan kecepatan angin.

Beberapa metode yang digunakan untuk prakiraan secara statistik diantaranya adalah Auto Regressive (AR), AR - Integrated Moving Average (ARIMA) kedua metode tersebut telah digunakan untuk prakiraan suhu udara. Metode 
konvensional tersebut banyak ditemui beberapa kelemahan. Dalam prakiraan dengan metode statistik, terdapat beberapa kelemahan salah satunya adalah prosentase ketidak tepatan ramalan pada saat kondisi cuaca yang sangat sulit untuk diprediksi secara matematis (Aisjah, 2012).[1]

Salah satu metode prakiraan yang dapat diaplikasikan dengan baik adalah neural network. Sistem kepakaran neural network mampu menyederhanakan sistem komplek, mampu beradaptasi dan mempunyai kelebihan dalam pembelajaran. Algoritma Jaringan Syaraf Tiruan (Neural network) yaitu mencoba membuat suatu model yang menirukan cara kerja jaringan syaraf manusia. Jaringan syaraf tiruan mampu melakukan pemodelan nonlinier tanpa mengetahui hubungan antara input dan variabel output sehingga pemodelan ini lebih umum dan fleksibel untuk prakiraan (Zhang, et al. 1997).[2]

Penelitian terkait tentang cuaca telah banyak dilakukan oleh beberapa peneliti dengan berbagai algoritma dan parameter data yang berbeda. Pada penelitian cuaca sebelumnya digunakan data analog dengan arsitektur single layer (Ernawati, Septima. 2009).[3] Didapatkan hasil penelitian pada kriteria cerah, output yang dihasilkan adalah nilai-nilai mendekati cerah, demikian juga pada kriteria hujan, output yang dihasilkan adalah nilai-nilai atau jarak menuju atau mendekati hujan. Arsitektur single-layer sangat terbatas sehingga hanya digunakan pada kasus yang sederhana dan memiliki keterbatasan dalam pengenalan pola. Kelemahan ini dapat ditanggulangi dengan arsitektur multilayer dengan menambahkan satu/beberapa layer tersembunyi diantara layer masukan dan layer keluaran. Pada arsitektur multilayer memiliki hidden layer yang bersifat variabel dan dapat digunakan pada sistem yang kompleks.

Algoritma pembelajaran yang digunakan pada arsitektur multilayer adalah algoritma backpropagation. Algoritma ini memiliki kelebihan yaitu mampu beradaptasi meskipun terjadi perubahan input karena terdapat proses training. Selama proses training, jaringan akan menyesuaikan bobot secara berulang sehingga dapat menghasilkan output yang diinginkan. Algoritma backpropagation bekerja berdasarkan pada pola data yang ada pada masa lalu. Dari sini dapat diketahui trend yang paling mirip dengan sekarang. Jika datanya cukup, maka prediksinya semakin bagus, dan tingkat akurasinya lebih baik.

\section{RUMUSAN MASALAH}

Rumusan masalah pada penelitian ini adalah Bagaimana memprakirakan curah hujan pada periode mendatang dengan menggunakan Algoritma neural network backpropagation berdasarkan pada data lampau.

\section{TUJUAN PENELITIAN}

Penelitian ini bertujuan untuk merancang prakiraan curah hujan Bandara Syamsudin Noor Banjarbaru menggunakan metode neural network backpropagation serta menggunakan Matlab R2013a sebagai software pengolahan data.

\section{TARGET LUARAN DAN MANFAAT PENELITIAN}

Target luaran dalam pembuatan penelitian ini adalah diharapkan dapat memberikan kontribusi dalam bidang transportasi udara dan Keselamatan dalam penerbangan .

Manfaat dari penelitian ini adalah memberikan pemahaman bahwa 
perkembangan sistem informasi dan komputer telah dapat digunakan di berbagai aspek kehidupan, salah satunya prakiraan dan sekaligus perencanaan untuk beberapa periode ke depan.

\section{METODE PENELITIAN}

Metode yang digunakan adalah dengan metode eksperimen, dengan tahapan penelitian seperti berikut:

\section{Pengumpulan Data (Data Gathering)}

Penelitian ini memakai data rentet waktu yaitu data curah hujan bulanan selama 5 Tahun mulai 2008 2012.

\section{Pengolahan Data ( Pre-processing)}

Sebelum digunakan untuk proses pelatihan, perlu dilakukan penskalaan terhadap nilai-nilai input dan target sedemikian hingga data-data input dan target tersebut masuk dalam suatu range tertentu yang disebut preprocessing atau normalisasi data.

\section{Pembagian Data}

Data dibagi menjadi data pelatihan dan pengujian. Komposisi yang akan digunakan pada penelitian ini: $80 \%$ sebagai data pelatihan dan $20 \%$ sebagai data pengujian. Aspek pembagian data harus ditekankan agar jaringan mendapat data pelatihan yang secukupnya dan data pengujian dapat menguji prestasi pelatihan yang dilakukan berdasarkan nilai MSE data pelatihan dan pengujian.

\section{Lokasi Penelitian}

Lokasi pengambilan data di BMKG Banjarbaru, Provinsi Kalimantan Selatan.

\section{ANALISIS HASIL DAN PEMBAHASAN \\ Data penelitian yang digunakan merupakan data sekunder yang berasal dari pengamatan secara langsung}

petugas di Bandara Syamsudin Noor Banjarbaru Provinsi Kalimantan Selatan. Data tersebut adalah data curah hujan selama 5 tahun mulai 2008 - 2012.

Tabel 1. Data curah hujan

\begin{tabular}{|c|r|r|r|r|r|r|r|r|r|r|r|r|}
\hline Thn/Bnn Januari & Februari & Maret & April & Mei & Juni & Juli & Agustus & September & Oktober & November Desember \\
\hline 2008 & 253.1 & 318.8 & 421.2 & 275.3 & 85.4 & 196.0 & 278.0 & 94.0 & 87.7 & 212.6 & 441.4 & 437.9 \\
\hline 2009 & 317.8 & 159.8 & 138.6 & 255.1 & 185.9 & 55.5 & 65.9 & 25.6 & 21.0 & 103.1 & 400.1 & 221.5 \\
\hline 2010 & 398.9 & 145.1 & 409.1 & 250.4 & 137.1 & 239.8 & 186.3 & 320.2 & 329.7 & 259.6 & 288.5 & 286.0 \\
\hline 2011 & 517.2 & 248.6 & 295.9 & 192.0 & 262.9 & 71.8 & 78.7 & 46.4 & 43.5 & 160.0 & 194.6 & 639.3 \\
\hline 2012 & 220.6 & 155.7 & 263.6 & 402.8 & 126.3 & 162.3 & 144.5 & 27.1 & 32.3 & 165.8 & 337.5 & 463.2 \\
\hline
\end{tabular}

Tabel 1 diatas adalah Tabel data bulanan curah hujan selama 5 Tahun (2008 s/d 2012), dari data bulanan tersebut nantinya akan dibagi 2 yaitu data untuk pelatihan dari tahun 2008-2011 (80\%) dan data untuk pengujian tahun 2012 (20\%) seperti pada tabel dibawah ini:

Tabel 2. Data curah hujan untuk pelatihan (2008-2011)

\begin{tabular}{|c|c|c|c|c|c|c|c|c|c|c|c|c|}
\hline $\mathrm{hn} / \mathrm{Bln}$ & & Februari & Maret & April & Mei & Juni & Juli & Agustus & September & Oktober & November & Desember \\
\hline 2008 & 253.1 & 318.8 & 421.2 & 275,3 & 85.4 & 196.0 & 278.0 & 94,0 & 87.7 & 212.6 & H1.4 & 437.9 \\
\hline 2009 & 317.8 & 159,8 & 138,6 & 255.1 & 185.9 & 55,5 & 65.9 & 25.6 & 21.0 & 103.1 & 400.1 & 221.5 \\
\hline 2010 & 398.9 & 145.1 & 409,1 & 250.4 & 137,1 & 239.8 & 186.3 & 320.2 & 329,7 & 259.6 & 288.5 & 286.0 \\
\hline 2011 & 517.2 & 248.6 & 2959 & 192.0 & 262.9 & 71.8 & \begin{tabular}{|l|}
78.7 \\
\end{tabular} & 46.4 & 43,5 & 160.0 & 194,6 & 639,3 \\
\hline
\end{tabular}

Tabel 3. Data curah hujan untuk pengujian (2012)

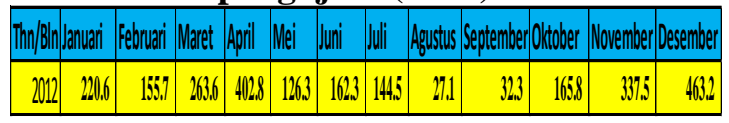

\section{Pengolahan Data}

Data bulanan curah hujan selama 12 bulan dijadikan sebagai inputan dan target adalah data curah hujan pada bulan ke-13. Jadi ada 36 pola data untuk pelatihan dan ada 12 pola data untuk pengujian.

\section{Algoritma Backpropagation}

Algoritma Backpropagation terdiri dari tiga tahapan atau fase yaitu:

\section{Fase I : Propagasi Maju}

Berawal dari pola pelatihan input (Feed Forward)

- Unit input menerima sinyal dan mengirimnya ke hidden unit (unit tersembunyi).

- Tentukan aktivasi dari hidden unit. 
Misal menggunakan logsig atau tansig.

- Kirim sinyal dari masing-masing hidden unit ke unit output.

- Hitung fungsi aktivasi dari output untuk membentuk respon dari net pola input.

\section{Fase II : Propagasi Mundur}

Menghitung error dan back propagasi dari error yang berhubungan

- Hitung selisih (Y-T) untuk menentukan error yang berhubungan antara pola dengan unit tersebut.

- Menghitung factor ( $\delta)$ yang digunakan untuk mendistribusikan error pada output $\mathrm{Y}$ ke unit-unit yang langsung berhubungan di lapisan sebelumnya.

- Menghitung factor ( $\delta)$ yang digunakan untuk mendistribusikan error pada unit-unit di Hidden layer ke unit-unit unput yang langsung berhubungan di lapisan sebelumnya.

\section{Fase III : Perubahan Bobot}

Melakukan update bobot baru dari Vji (input Xi dengan hidden $\mathrm{Zj}$ ) dan $\mathrm{Wjk}$ (Hidden $\mathrm{Zj}$ dengan output $\mathrm{Yk}$ ) atau dengan memodifikasi bobot untuk menurunkan kesalahan yang terjadi.

\section{Flowchart Backpropagation}

Gambar berikut ini merupakan flowchart Jaringan Syaraf Tiruan Backpropagation yang diterapkan pada penelitian ini:

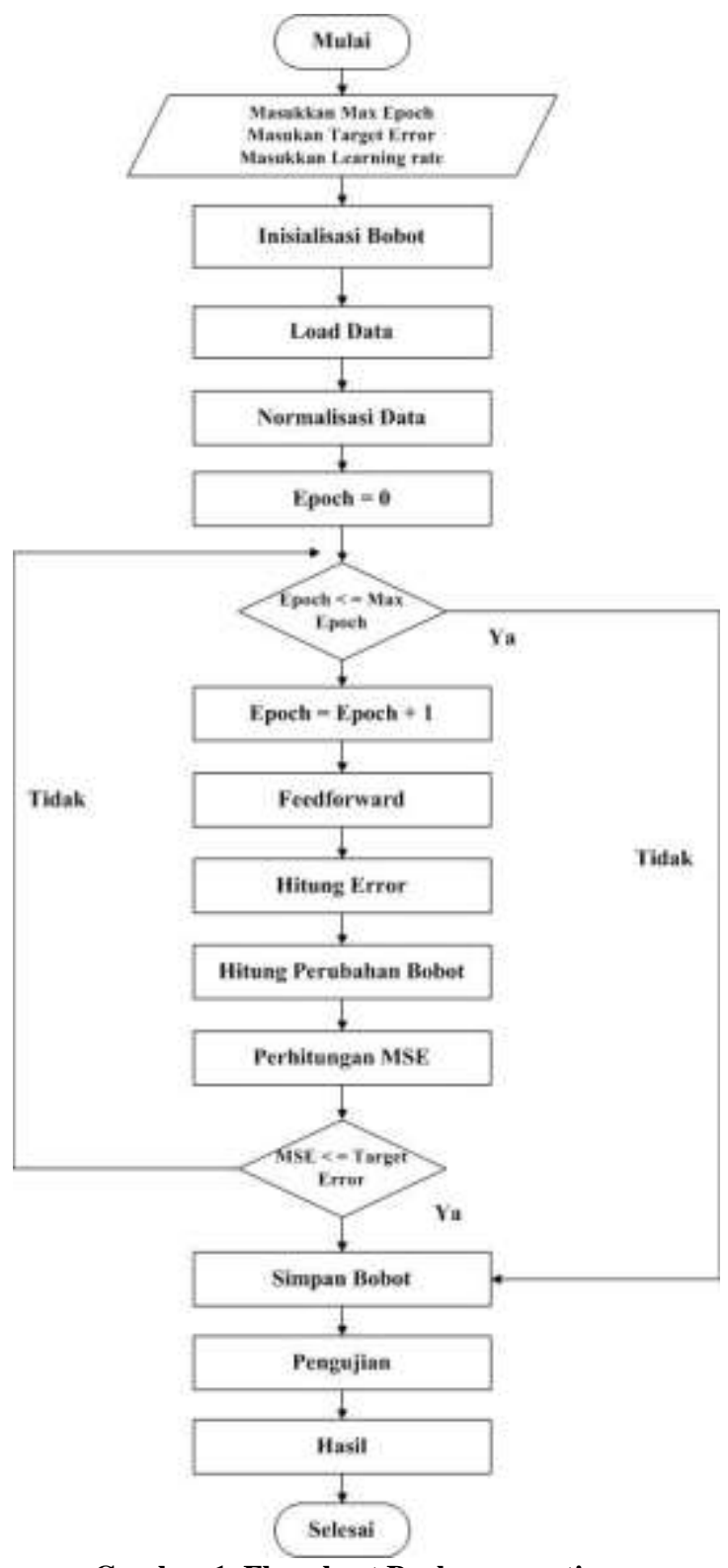

Gambar 1. Flowchart Backpropagation

\section{Hasil Pengujian}

pengujian akan dilakukan terhadap data-data yang tidak ikut dilatih ( Data pengujian sebanyak 12 Data berupa data Tahun 2012), dengan data Cek disimpan pada matriks Q untuk input data dan matriks TQ untuk target.

o Input Baru Q akan di Tes, dengan target $\mathrm{TQ}$

$\mathrm{Cek}=\left[\begin{array}{lll}517.2 & 248.6 & 295.9\end{array}\right.$

$\begin{array}{llll}192.0 & 262.9 & 71.8 & 78.7\end{array}$

$\begin{array}{llll}46.4 & 43.5 & 160.0 & 194.6\end{array}$

639.3220 .6

$\begin{array}{llll}248.6 & 295.9 & 192.0 & 262.9\end{array}$

$\begin{array}{llll}71.8 & 78.7 & 46.4 & 43.5\end{array}$ 


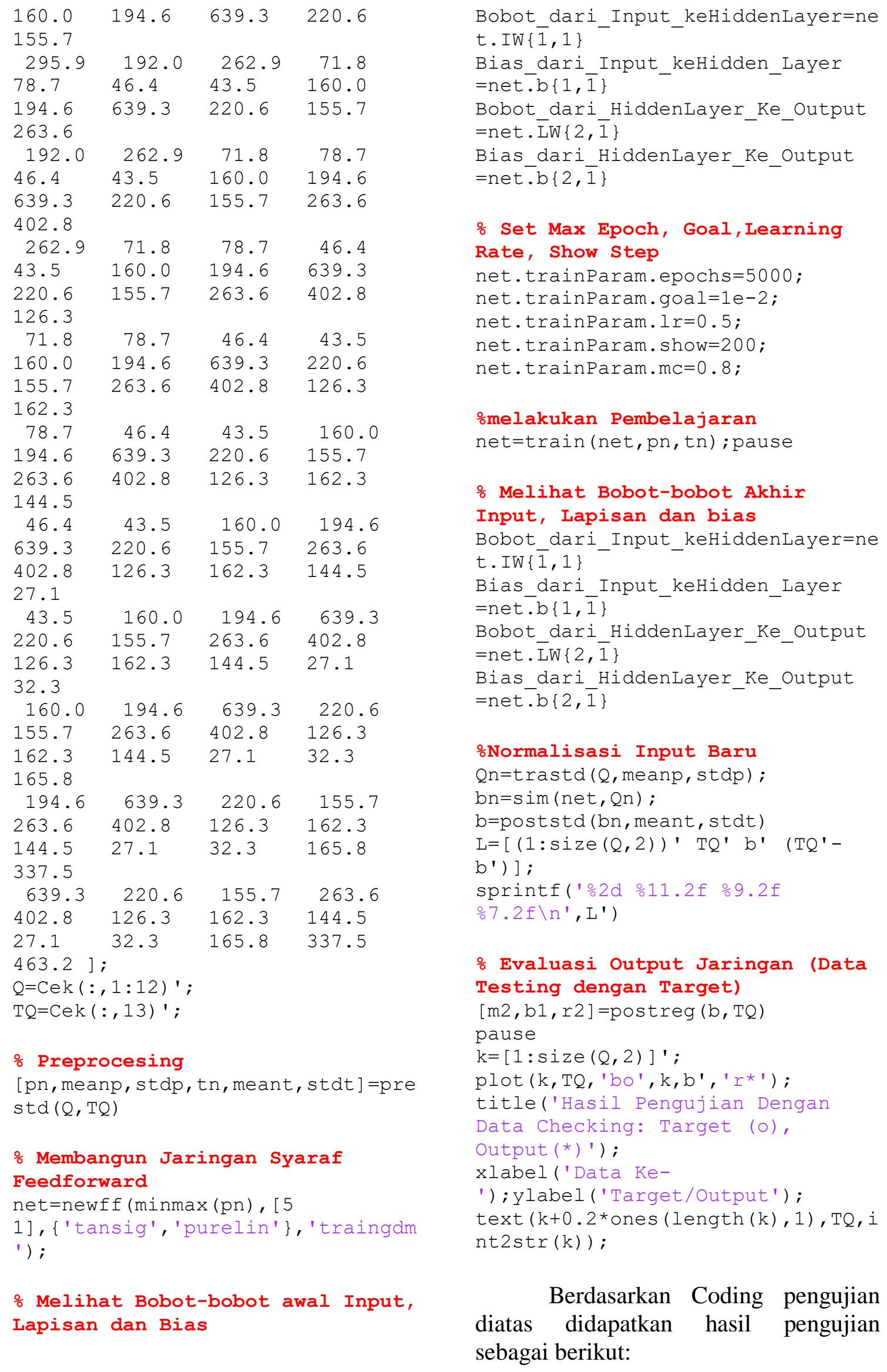



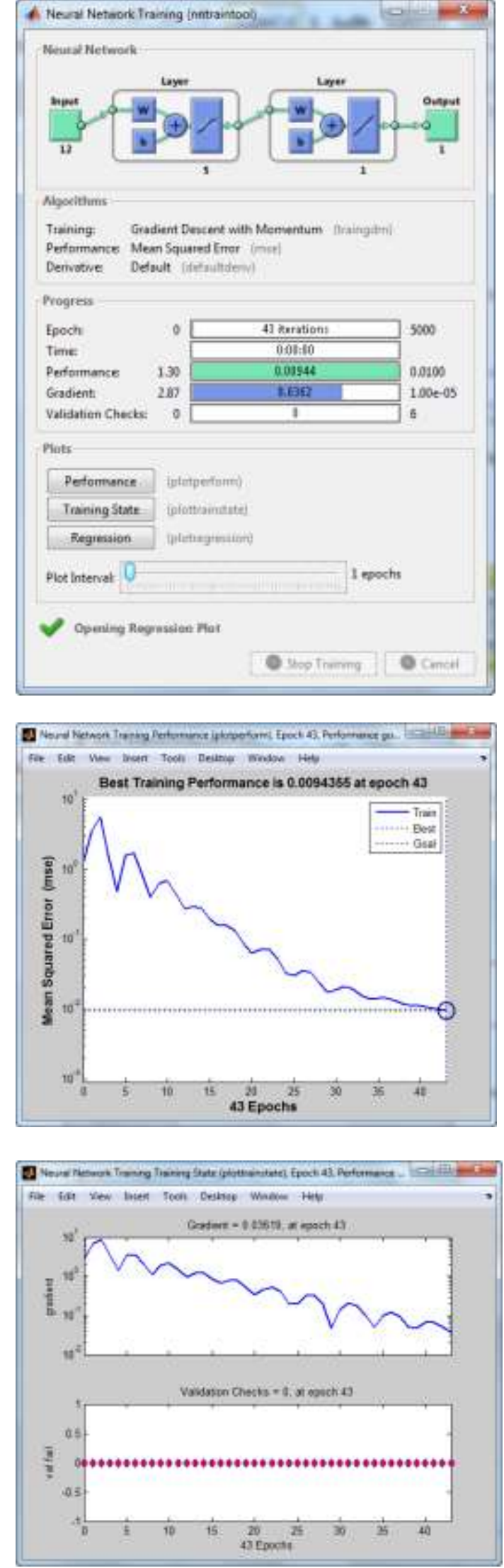

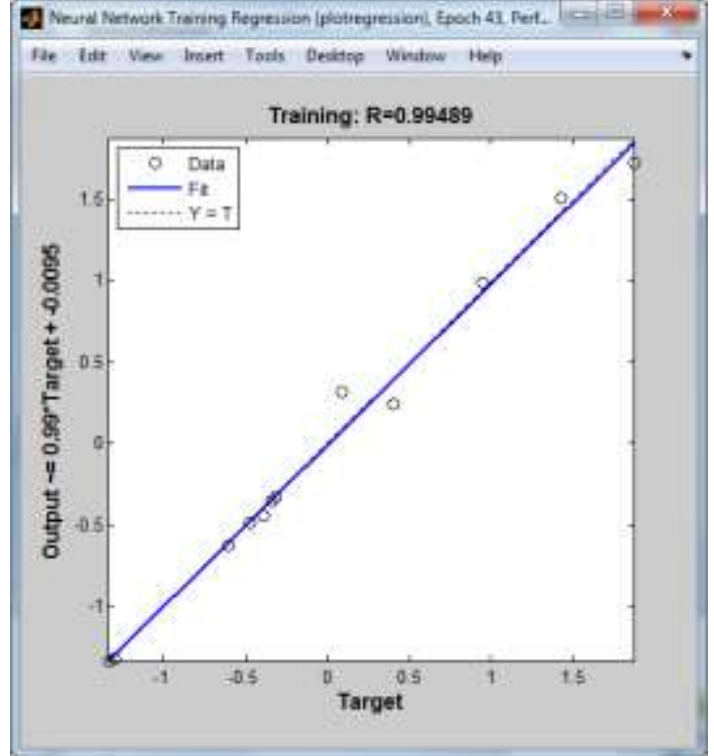

\section{Gambar 2, 3, 4 dan 5 Hasil keseluruhan Pengujian (Checking) Data) Data}

Hasil akhir dari pengujian data (Checking) adalah sebagai berikut:

a. Pada hasil Pengujian terhadap 12 pola data inputan, dapat diketahui dari 5000 epoch yang telah ditentukan, data berhenti dan mencapai hasil pada epoch ke-43. Karena unjuk kerja (mse 1e-2) terlampaui pada epoch ke-43 dengan nilai mse 0.0100 .

b. Performa yang dihasilkan adalah 0.0094355 dengan target mse 0.0100 pada epoch ke-43.

c. Gradient yang dihasilkan pada epoch ke-43 adalah 0.03619

d. Plot data dengan Tanda 'o' adalah merupakan data pengujian, garis putus putus merupakan target $(\mathrm{Y}=\mathrm{T})$ sedangkan garis biru adalah Fit data, berdasarkan gambar diatas bahwa data checking (uji) sudah bisa dikenali dengan baik.

Dari tabel dibawah dapat diketahui Error terkecil terletak pada data ke-1 yaitu sebesar -30.8229, Sedangkan Error 
terbesar terletak pada data ke-3 yaitu sebesar 22.33341.

Tabel 4. Hasil Pengujian backpropagation

\begin{tabular}{|r|r|r|r|}
\hline No & Target (TQ) & \multicolumn{1}{|c|}{ Output (b) } & Error (E=TQ-b) \\
\hline 1 & 220.6 & 251.42289 & $\mathbf{- 3 0 . 8 2 2 8 8 5 4 6}$ \\
\hline 2 & 155.7 & 148.73665 & 6.963353368 \\
\hline 3 & 263.6 & 241.26659 & $\mathbf{2 2 . 3 3 3 4 1 2 1 2}$ \\
\hline 4 & 402.8 & 413.64971 & -10.84971041 \\
\hline 5 & 126.3 & 122.96562 & 3.334380782 \\
\hline 6 & 162.3 & 160.68326 & 1.616737912 \\
\hline 7 & 144.5 & 142.75583 & 1.744168083 \\
\hline 8 & 27.1 & 26.718204 & 0.381796373 \\
\hline 9 & 32.3 & 28.744026 & 3.555973975 \\
\hline 10 & 165.8 & 163.95984 & 1.840163998 \\
\hline 11 & 337.5 & 342.7158 & -5.215802754 \\
\hline 12 & 463.2 & 442.59361 & 20.60638802 \\
\hline
\end{tabular}

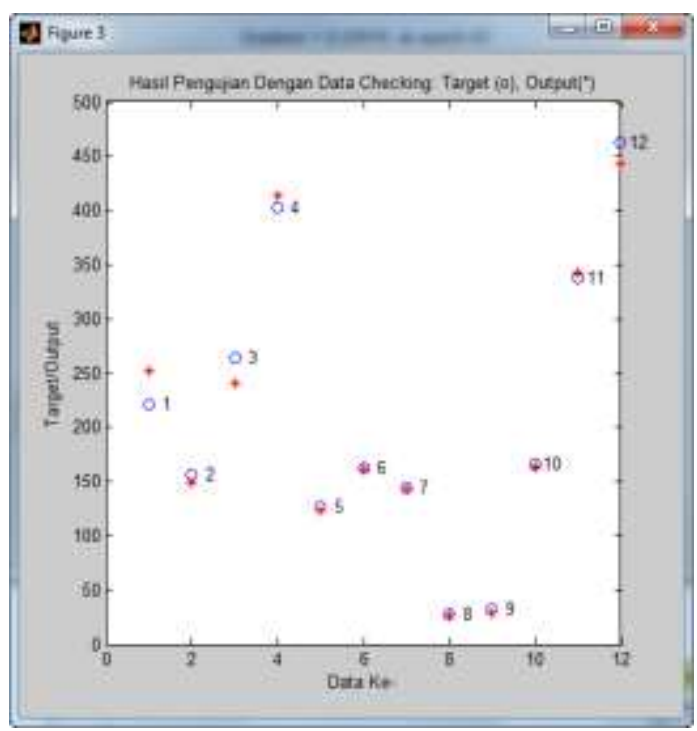

Gambar 6 Perbandingan Target dengan Output untuk data Pengujian.

\section{PENUTUP}

Kesimpulan

Berdasarkan dari hasil penelitian ini dapat ditarik kesimpulan sebagai berikut:

1. perbandingan Antara Target dan Output, dimana Target berwarna biru(o) sedangkan Output berwarna Merah (*). Dapat dilihat bahwa Ouput jaringan (o) dan Target (*) sebagian besar sudah berdekatan (hampir menempati posisi yang sama). ini menunjukan bahwa backpropagation dapat mengenali target dari pola data dengan baik, pada saat pelatihan maupun saat pengujian. Hasil terbaik terjadi apabila posisi (o) dan (*) betul-betul berada pada posisi yang sama.

2. Didapatkan Arsitektur jaringan terbaik untuk data curah hujan bulanan dengan 12 inputan, 5 neuron hidden layer dan 1 output ( $12-5-$ 1) dengan menggunakan parameter 5000 Epoch, MSE 1e-2 atau 0.01 dengan laju pemahaman (learning rate) 0.5 .

3. Hasil terbaik saat pelatihan untuk Analisis Regresi Linear adalah: m1 $($ Gradient garis terbaik $)=\mathbf{0 . 9 8 8 5}$

penjelasan: $\mathbf{m}$ adalah Gradient garis hasil regresi linear. Apabila output tepat sama dengan targetnya, maka Gradient ini akan bernilai 1. Dari hasil $\mathbf{m}$ didapat oleh MATLAB maka output jaringan hampir sama dengan targetnya. a1 (Konstanta) $\mathbf{=} \mathbf{2 . 5 2 3 7}$

Penjelasan : a adalah titik perpotongan dengan sumbu y. Apabila output jaringan tepat sama dengan targetnya, maka perpotongan dengan sumbu y ini akan bernilai 0 . Dari hasil a yang didapat oleh MATLAB maka output jaringan saat pelatihan masih jauh dengan targetnya. $\mathbf{r 1}=\mathbf{0 . 9 9 4 9}$

penjelasan : $\mathbf{r}$ adalah koofesien korelasi antara output jaringan dengan target. Apabila output jaringan tepat sama dengan targetnya. Maka koofesien korelasi ini akan bernilai 1 . Dari hasil $\mathbf{r}$ yang didapat oleh MATLAB maka output jaringan hampir tepat sama dengan targetnya.

4. Hasil terbaik saat pengujian untuk Analisis Regresi Linear adalah: m2 $($ Gradient garis terbaik $)=\mathbf{0 . 9 9 1 6}$ penjelasan: $\mathbf{m}$ adalah Gradient garis hasil regresi linear. Apabila output tepat sama dengan targetnya, maka Gradient ini akan bernilai 1. Dari hasil $\mathbf{m}$ didapat oleh MATLAB maka 
output jaringan hampir sama dengan targetnya. a2 (Konstanta) $\mathbf{= 0 . 4 7 0 2}$

Penjelasan : a adalah titik perpotongan dengan sumbu $y$. Apabila output jaringan tepat sama dengan targetnya, maka perpotongan dengan sumbu y ini akan bernilai 0 . Dari hasil a yang didapat oleh MATLAB maka output jaringan saat pengujian hampir tepat dengan targetnya. $\mathbf{r} \mathbf{2}=\mathbf{0 . 9 9 4 9}$

penjelasan : $\mathbf{r}$ adalah koofesien korelasi antara output jaringan dengan target. Apabila output jaringan tepat sama dengan targetnya. Maka koofesien korelasi ini akan bernilai 1 . Dari hasil $\mathbf{r}$ yang didapat oleh MATLAB maka output jaringan hampir tepat sama dengan targetnya.

Dengan demikian, Algoritma Backpropagation sangat baik dalam memprediksi dan dapat mengenali dengan baik pola data curah hujan.

\section{Saran}

Penelitian ini dapat dikembangkan dengan menggunakan metode pembelajaran neural network lainnya atau dapat dibandingkan dengan metode JST lainnya seperti RBF ( Radial Basis Function).

Untuk penelitian selanjutnya bisa dikembangkan lagi, tidak hanya prakiraan curah hujan tapi bisa memprakirakan cuaca dengan menambah variabel lain seperti variabel input terdiri dari suhu udara, kelembaban udara, tekanan udara dan untuk output yaitu kecepatan angin dan curah hujan.

\section{DAFTAR PUSTAKA}

[1] Aisjah, Aulia S. 2012. Aplikasi Sistem Logika Fuzzy pada Prakiraan Cuaca Indonesia Studi Kasus: Cuaca Kota Surabaya. Teknik Fisika Institut Teknologi Sepuluh Nopember Surabaya.
[2] ENSO-like Interdecadal Variability: 1900-93 Yuan Zhang, John M Wallace. And David S Batisti Department of Atmospheric Sciences, University of Washington, Seattle, Washington (Manuscript received 2 January 1996, in final form 18 June 1996), 1997.

[3] Ernawati, Septima. 2009. Aplikasi Hopfield Neural network untuk Prakiraan Cuaca. Jurnal Meteorologi dan Geofisika. 10 (2): 151-175.

[4] Kadarsah and Ahmad Sasmita, "Standardisasi Metadata Klimatologi Dalam Penelitian Perubahan Iklim Di Indonesia," in Prosiding PPI Standardisasi 2010, Banjarmasin, 2010, pp. 1-18.

[5] Handoko, Ed., Klimatologi Dasar. Jakarta: Pustaka Jaya, 1994.

[6]http://id.wikipedia.org/wiki/Bandar_ Udara_Syamsudin_Noor Tanggal Akses 8 Oktober 2013.

[7] Suyanto, "Artificial Intelligenc: Searching, Reasoning, Planning, and Learning". Bandung: Penerbit Informatika, 2007.

[8] Siang Jong Jek, "Jaringan Syaraf Tiruan dan Pemrogramannya", 2nd ed. Yogyakarta: Penerbit Andi, 2009.

[9] J.J.Siang. 2004. Jaringan Syaraf Tiruan dan Pemrogramannya Menggunakan Matlab. Yogyakarta. ANDI.

[10] Sri Kusuma dewi,"Jaringan Syaraf Tiruan dengan Metode BPNN",2004.

[11] Fausett, Laurene V. 1994. Fundamentals of Neural network : Architechture, Algoritms, and Applications. New Jersey. Prentice Hall. 